\title{
GROWTH AND YIELD OF MONOSEX TILAPIA OREOCHROMIS NILOTICUS IN FLOATING CAGES FED COMMERCIAL DIET SUPPLEMENTED WITH PROBIOTICS IN FRESHWATER POND, SYLHET
}

\author{
N. Begum*, M. S. Islam, A. K. M. F. Haque and I. N. Suravi \\ Department of Coastal and Marine Fisheries, Sylhet Agricultural University, \\ Sylhet-3100, Bangladesh
}

\begin{abstract}
The effect of probiotics mixed with floating feed on the growth and production of tilapia Oreochromis niloticus over a period of 120 days was evaluated. Four treatments were $\mathrm{T}_{1}$ (super biotic probiotics), $\mathrm{T}_{2}$ (biozyme probiotics), $\mathrm{T}_{3}$ (zymetin probiotics) and $\mathrm{T}_{4}$ (control) with three replicates. Higher growth of tilapia was found in $\mathrm{T}_{3}(272.78 \mathrm{~g})$ followed by $\mathrm{T}_{2}(242.56 \mathrm{~g}), \mathrm{T}_{1}(222.76 \mathrm{~g})$ and $\mathrm{T}_{4}(199.35 \mathrm{~g})$. The highest gross yield $\left(8.82 \mathrm{~kg} \mathrm{~m}^{-3}\right)$ was achieved in $\mathrm{T}_{3}$ compared to $\mathrm{T}_{2}\left(7.78 \mathrm{~kg} \mathrm{~m}^{-3}\right), \mathrm{T}_{1}\left(7.23 \mathrm{~kg} \mathrm{~m}^{-3}\right)$ and $\mathrm{T}_{4}\left(6.35 \mathrm{~kg} \mathrm{~m}^{-3}\right)$, which is manifolds higher than the earthen pond yield of tilapia in Bangladesh. The highest net profit (TK. $401.0 \mathrm{~m}^{-3}$ ) was obtained in $\mathrm{T}_{3}$ and the lowest (TK. $119.0 \mathrm{~m}^{-3}$ ) was in control $\left(\mathrm{T}_{4}\right)$. Results suggest that probiotics can be used in feed to increase fish production.
\end{abstract}

Key words: Feed, probiotics, yield, tilapia, Bangladesh

\section{INTRODUCTION}

Tilapia Oreochromis niloticus are being used in commercial farm in more than 100 countries of the world from extensive to super-intensive and one of the important fishes in aquaculture industry in this century. Tilapia is the second most cultured fish worldwide after the carps and even though they are easily cultured in a wide variety of environment and are relatively resistant to aquaculture stressors compared to other cultured fin fishes (Hussain 2004). Tilapia is randomly cultured in brackishwater environment though it is a freshwater fish. This fish is palatable and hardy can survive in very low depth of water $(15 \mathrm{~cm})$. Tilapia culture in rural areas of Bangladesh is increasingly becoming popular. The rural Bangladesh is 20,60,408 $\mathrm{mt}$ in closed waterbodies production of tilapia contributed 1,52,884 $\mathrm{mt}$ in 2014-2015 but it was 1,38,000 $\mathrm{mt}$ of $18,59,808 \mathrm{mt}$ in 2012-2013 (DoF 2016). Carps are easily affected by bacterial and fungal diseases but tilapia suffers less although tilapia lake virus disease has been reported in some tropical country including Bangladesh. As a result, farmers have been found reluctant to stock carps in their small ponds and seasonal water bodies. To protect diseases and for getting quick return,

*Author for correspondence: <nasimasau@gmail.com>.

(C) 2017 Zoological Society of Bangladesh DOI: http://dx.doi.org/10.3329/bjz.v45i1.34191 
most of the farmers shifted their culture practice into tilapia production in their seasonal ponds. Tilapia in different countries is farmed with fertilization and/or supplementary feeding. Supplemental feeds are given to increase yield above produced with fertilization alone. In fish farming practices, stocking density is considered to be one of the important factors that affect fish growth and survival, feed utilization and yield (Liu and Chang 1992). Furthermore, it has been reported that stocking density is a key factor in determining the productivity and profitability of commercial fish farms (Ellis et al. 1952). Feed is the highest cost oriented input in aquaculture. Thus the higher the effective feed the less will be the cost of production.

Monosex tilapia $O$. niloticus does not breed/multiply, which makes it easy for fish farmers to avoid uncontrolled breeding in their farms. They grow fast and attain market size within a short period in pond, cage and pen than other tilapia forms. Monosex tilapia become marketable size (100-150 g) within 2-3 months. Size of tilapia is entirely dependent on the size of pond/cage/pen, natural productivity of water, feed quality, frequent of feeding, stocking density, size of fry/fingerlings and management. Among different forms of tilapia, monosex is more suitable for cage culture because tilapia does not jump. This fish is currently considered to be the most important and commonly cultured species around the world and constitutes over $70 \%$ of cultured tilapia (Fitzsimmons 2004) which represent approximately $6 \%$ of total farmed fish production (FAO 2004).

Probiotics are feed additives defined as live microbes that may serve as dietary supplements to improve the host intestinal microbial balance and growth performance (Gatesoupe 1999). The probiotics in aquaculture have been shown to have several modes of action: competitive exclusion of pathogenic bacteria through the production of inhibitory compounds, improvement of water quality, enhancement of immense response of host species and enhancement of nutrition of host through the production of inhibitory of supplemental digestive enzymes (Carnevali and Cresci 2006). Thus the use of probiotic in aquaculture has received some attention (Abdel et al. 2002).

Use of probiotics as farm animal feed supplements dates back to the 1970s. They were originally incorporated into the feed to increase the animal's growth and improve its health by increasing its resistance to disease (Fuller 1992). Today, probiotics are quite common place in health promoting "functional foods" for humans, as well as therapeutic, prophylactic and growth supplements in animal production and human health (Geovanny et al. 2007). Most studies on probiotics in aquaculture have been used in in vitro models of specific bacteria as antagonists of pathogens. The use of probiotics in aquaculture has been 
accompanied by an increase in nutrient utilization through providing enzymes capable of converting certain components of the diet into more digestible nutrients for the host. With increasing demand for environment friendly aquaculture, the use of probiotics in aquaculture is now widely accepted (Gatesoupe 1999 and Moriarty 1998). Though several types of probiotics (Aqua photo, Aqua mazic, Ammonil, Safegut, Probio-Aqua, Super biotic, Super P S) in powder or liquid forms are found in the markets, most of the farmers do not know the techniques of use and impact of these probiotics. A few work have been done on probiotics in shrimp culture in brackishwater to determine the mode of application of Bacillus probiotics (Islam et al. 2008). Very few studies related to the usage of probiotics in aquaculture are available in Bangladesh. Therefore, there is a need to understand the effects of probiotics in artificial diet of tilapia cage culture. The objectives of this study were to determine the effects of dietary supplementation of commercial probiotics on growth and production performance of tilapia in the freshwater cage in the pond.

\section{MATERIAL AND METHODS}

Experimental animal and conditioning: Tilapia fry were purchased from a private hatchery and were transported in oxygenated polythene bags from the hatchery to University campus. Before stocking, fry were acclimatized to the pond water for one hour period. Initial weight and length of 25 fish were recorded before stocking in the cages. The study was undertaken in 12 nylon net cages installed in a pond of Sylhet Agricultural University (SAU) campus, Sylhet over 120 days from 15 July to 12 November 2015.

Experimental system: Twelve newly constructed cages $(1.5 \times 1 \times 1 \mathrm{~m})$ were used as culture system. Frame of cage was made of bamboo split. Plastic drums were used as cage float. Net cages were made of plastic or knot-less polyethylene net $($ mesh $1.0 \mathrm{~cm})$. Cages were hanged with cage frame. Bamboo made platform was set up over the cages and all cages were fixed with the poles of the platform. Cages were installed at both sides of the platform for easily feed supply and intensive observation.

Experimental design: This study was a one factorial in which types of probiotics were the only experimental variable such as $\mathrm{T}_{1}$ (super biotic), $\mathrm{T}_{2}$ (biozyme), $\mathrm{T}_{3}$ (zymetin) and $\mathrm{T}_{4}$ (control) with three replicates. Pond selected for setting the cages was cleaned manually and limed with $\mathrm{CaO} @ 250 \mathrm{~kg} \mathrm{ha}^{-1}$. After that the ponds were fertilized with urea and TSP @ 25 and $37.5 \mathrm{~kg} \mathrm{ha}^{-1}$, respectively. After 6 days of fertilization, cages were stocked with required quantity of fry of male Nile tilapia $O$. niloticus at a density of $35 \mathrm{~m}^{-3}$ with $3.0 \pm$ $0.11 \mathrm{~g}$ size in each cage. 
Proximate composition of the feed ingredients: The commercial mega feed fed tilapia was analyzed to determine moisture, crude protein, crude lipid, ash, crude fibre and carbohydrate following AOAC methods (2000). Moisture, crude protein, crude lipid, ash, crude fibre and carbohydrate of the feed were 24.19, $10.11,7.85,22.65,6.04$ and $29.16 \%$, respectively.

Culture of tilapia: After liming and fertilization, water colour of the pond turned into green. Then cages were stocked with all male tilapia fry. Artificially manufactured probiotics (beneficial bacteria) was mixed with commercial feed before application @ $0.5 \mathrm{~g} \mathrm{~kg}^{-1}$ feed following the instruction of the manufacturer. Stocked fry of tilapia were fed commercial floating diet at the decreasing rate of $10-5 \%$ of body weight thrice daily until the previous day of harvest.

Super biotic (Bacillus sp. recommended by manufacturer at strength of $10^{7}$

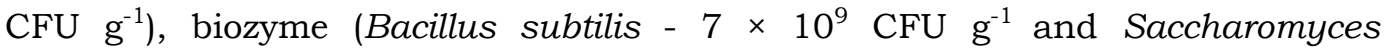
cerevisiae $-3 \times 10^{12}$ cells) and zymetin (Bacillus mesentericus, Streptococcus faecalis and Clostridium butyricum) were used with feed to assess their role on growth and yield of tilapia.

Sampling: Fish was sampled fortnightly to determine the growth and to adjust the feed rations. Body weight (g) was measured with a digital balance (CAMRY digital electrical balance Model EK 3052, Bangladesh). Behavior of tilapia was regularly observed especially after feeding in the morning and in the evening to determine their conditions such as movement, infection, colorations and diseases. Sampling was continued until harvest.

Water quality variables: Water quality variables viz. temperature, transparency, dissolved oxygen (DO) concentration, $\mathrm{pH}$, total alkalinity, nitrate and ammonia were measured fortnightly intervals between 09 and 10 a.m. at the time of fingerling sampling. Surface water temperature was measured in situ by using a standard centigrade thermometer. Transparency was recorded by using a Secchi disc. Dissolved oxygen was measured by using a portable DO meter (YSI digital DO meter, Model 58, HANNA Company, USA). Pond water $\mathrm{pH}$ was monitored by using a hand held $\mathrm{pH}$ meter (Digital pH meter, Model HI 98107 HANNA Company, USA). Total alkalinity was measured by titrimetric method (APHA 2000). Nitrate and ammonia were measured by using nitrate and ammonia test kit, respectively (Biosol, A.A. Biotech PVT LTD., Fishtech BD LTD).

Harvest: Tilapia was harvested after 120 days of culture. All fish were caught from each cage at the same day by scooping. After harvest, all tilapia of the cages were counted and weighed individually to determine the survival rate, growth and yield. Survival rate (\%), specific growth rate (SGR), food conversion ratio (FCR) and protein efficiency ratio (PER) were calculated following the 
equation as cited by Pechsiri and Yakupitiyage (2005). The equations are as follows:

Survival rate (\%): (Number of fish harvested $\div$ Number of fish stocked) $\times 100$

SGR (\% day $\left.{ }^{-1}\right):\{\operatorname{Ln}$ (final body weight)-Ln (initial body weight) $\times$ $100\} /$ cultured period (day).

Feed conversion ratio (FCR): Feed consumed (g dry weight)/Live weight gain (g wet weight) of fish.

Protein efficiency ratio (PER): Weight gain (g)/protein consumed (g).

Yield: No. of fish caught $\times$ average final weight of fish.

Net profit margin: (Net profit/Sales) $\times 100$.

Data analysis: Survival and growth rate were transformed into square root before analysis. Mean were compared by using 1-way followed by Tukey's HSD post hoc for multiple comparisons. Level of significance considered in this study was $p<0.05$ by using SPSS (Statistical Package for Social Science) version 20.0.

\section{RESULTS AND DISCUSSION}

Survival rate and growth rate: Survival rate of tilapia ranged from 89.52 to $91.43 \%$ (Table 1). In a previous study, survival rate of caged tilapia had been found to range from 95.76 to $97.54 \%$ (Ahmed et al. 2014) and 95.39 to $95.87 \%$ (Kunda et al. 2015), which are similar to the findings of present study.

Significantly higher final weight of tilapia was found in $\mathrm{T}_{3}(275.88 \mathrm{~g})$ than those of $\mathrm{T}_{4}(202.45 \mathrm{~g}), \mathrm{T}_{1}(225.88 \mathrm{~g})$ and $\mathrm{T}_{2}(245.68 \mathrm{~g})$, respectively (Fig. 1 and Table 1). The highest growth obtained in $\mathrm{T}_{3}$ might be due to probiotics zymetin, which is very fine and attractive smell, and having three beneficial bacteria. Final weight of tilapia obtained in the present study is in agreement with the findings of Ahmed et al. (2014), who found final weight of tilapia as 207.90 $271.48 \mathrm{~g}$ at $50 \mathrm{~m}^{-3}$ densities over 120 days rearing in suspended cages fed commercial diet supplemented with probiotics at Dakatia river, Chandpur. Kunda et al. (2015) has demonstrated that final weight of tilapia attained from 167.15 to $189.67 \mathrm{~g}$ for a 99 days period reared in net cages given floating feed without probiotics in a pond of Sylhet Agricultural University (SAU). Daily weight gain of tilapia varied from 1.69-2.30 g (Table 1) which is in agreement with the findings of Ahmed et al. (2014) who obtained daily weight gain $1.45-1.98 \mathrm{~g}$ by applying commercial floated feed with probiotics in cages. Ahmed et al. (2013) has also found daily weight gain $1.56 \mathrm{~g}$ by applying prepared feed and $1.78 \mathrm{~g}$ by using commercial feed for tilapia reared for 70 days period. 
The highest SGR was found in $\mathrm{T}_{3}(4.67 \%)$ while the lowest in the control group (Table 1). SGR found in other two treatments were also significantly different.

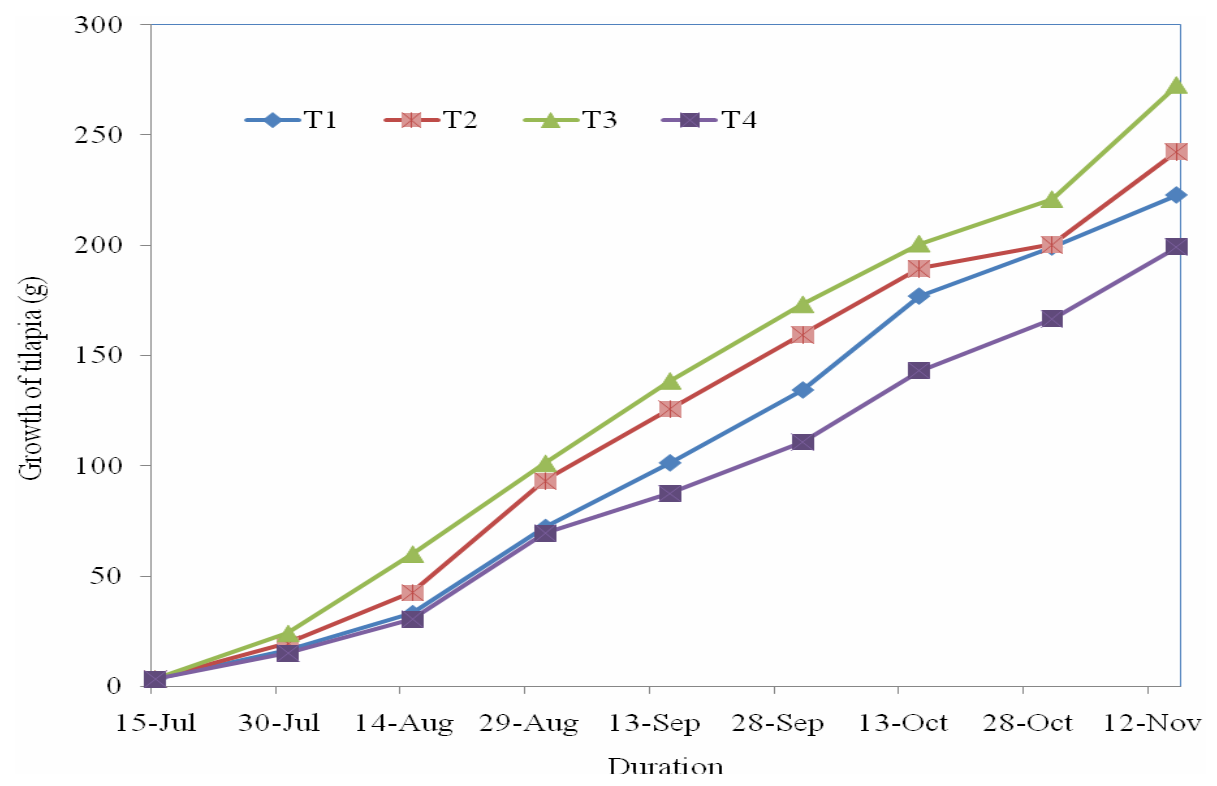

Fig. 1. Growth of tilapia measured in different treatments over 120 days culture duration.

Table 1. Survival rate, growth and yield performance (mean \pm Sd) of male tilapia found in four treatments over 120 days culture

\begin{tabular}{llccc}
\hline \multirow{2}{*}{ Variables } & \multicolumn{4}{c}{ Treatments } \\
\cline { 2 - 5 } & \multicolumn{1}{c}{$\begin{array}{c}\mathrm{T}_{1} \\
\text { (Super biotic) }\end{array}$} & $\begin{array}{c}\mathrm{T}_{2} \\
\text { (Biozyme) }\end{array}$ & $\begin{array}{c}\mathrm{T}_{3} \\
\text { (Zymetin) }\end{array}$ & $\begin{array}{c}\mathrm{T}_{4} \\
\text { (Control) }\end{array}$ \\
\hline Stocking density (nos. $\mathrm{m}^{-3}$ ) & 35 & 35 & 35 & 35 \\
Survival rate (\%) & $91.42 \pm 2.86$ & $90.48 \pm 1.65$ & $91.43 \pm 2.86$ & $89.52 \pm 4.37$ \\
Average initial weight (g) & $3.0 \pm 0.11$ & $3.0 \pm 0.11$ & $3.0 \pm 0.11$ & $3.0 \pm 0.11$ \\
Average final weight (g) & $225.88 \pm 5.95^{\mathrm{bc}}$ & $245.68 \pm 13.88^{\mathrm{ab}}$ & $275.88 \pm 13.6^{\mathrm{a}}$ & $202.45 \pm 14.71^{\mathrm{c}}$ \\
Net final weight gain (g) & $222.78 \pm 5.95^{\mathrm{c}}$ & $242.56 \pm 13.88^{\mathrm{bc}}$ & $272.78 \pm 13.6^{\mathrm{a}}$ & $199.35 \pm 14.71^{\mathrm{c}}$ \\
Daily weight gain (g) & $1.88 \pm 0.05^{\mathrm{bc}}$ & $2.04 \pm 0.12^{\mathrm{ab}}$ & $2.30 \pm 0.12^{\mathrm{a}}$ & $1.69 \pm 0.12^{\mathrm{c}}$ \\
Specific growth rate (\% day ${ }^{-1}$ ) & $4.48 \pm 0.03^{\mathrm{bc}}$ & $4.55 \pm 0.06^{\mathrm{b}}$ & $4.67 \pm 0.05^{\mathrm{a}}$ & $4.37 \pm 0.07^{\mathrm{c}}$ \\
FCR & $1.23 \pm 0.04^{\mathrm{b}}$ & $1.14 \pm 0.07^{\mathrm{bc}}$ & $1.01 \pm 0.05^{\mathrm{c}}$ & $1.38 \pm 0.1^{\mathrm{a}}$ \\
PER & $2.53 \pm 0.07^{\mathrm{a}}$ & $2.76 \pm 0.16^{\mathrm{a}}$ & $3.1 \pm 0.16^{\mathrm{b}}$ & $2.26 \pm 0.17^{\mathrm{a}}$ \\
Gross yield $\left(\mathrm{kg} \mathrm{m}^{-3}\right.$ ) & $7.23 \pm 0.41^{\mathrm{bc}}$ & $7.78 \pm 0.31^{\mathrm{ab}}$ & $8.82 \pm 0.36^{\mathrm{a}}$ & $6.35 \pm 0.74^{\mathrm{c}}$ \\
Net yield $\left(\mathrm{kg} \mathrm{m}^{-3}\right.$ ) & $7.13 \pm 0.41^{\mathrm{bc}}$ & $7.68 \pm 0.31^{\mathrm{ab}}$ & $8.72 \pm 0.32^{\mathrm{a}}$ & $6.25 \pm 0.73^{\mathrm{c}}$ \\
\hline
\end{tabular}

Mean values in the same row with same superscript letters are not significantly different $(\mathrm{p}<0.05)$. 
SGR values observed in the present study is in agreement with the SGR value $(4.60-4.72 \%)$ reported by Kunda et al. (2015). However, SGR value of this study was comparatively higher than the values of 2.97 - 3.09 and $3.10 \%$, respectively demonstrated by Ahmed et al. (2013) and Diana et al. (1996).

Fish yield: The gross yield of tilapia obtained from all treatments ranged from 6.35 to $8.82 \mathrm{~kg} \mathrm{~m}^{-3}$ with the highest yield $\left(8.82 \mathrm{~kg} \mathrm{~m}^{-3}\right)$ in $\mathrm{T}_{3}$ and the lowest yield $\left(6.35 \mathrm{~kg} \mathrm{~m}^{-3}\right)$ in $\mathrm{T}_{4}$ (Table 1). Ahmed et al. (2014) obtained $9.93-11.63 \mathrm{~kg} \mathrm{~m}^{-3}$ of tilapia in cages at $50 \mathrm{~m}^{-3}$ densities, which is slightly higher than the yield of the present study. The fish yield of the present study is almost similar to the yield $\left(7.7-9.4 \mathrm{~kg} \mathrm{~m}^{-3}\right)$ reported by Alam et al. (2014).

Food conversion ratio (FCR) of tilapia in this investigation was $1.01-1.38$ (Table 1). However, FCR of tilapia in this study is similar to the findings of Kunda et al. (2015) and Ahmed et al. (2014), who found FCR of tilapia 1.18-1.25 and 1.111.41 , respectively.

Protein efficiency ratio (PER) for tilapia yield in the present study varied from 3.1 - 2.26, which coincided with the finding of Saha and Khatun (2014), who found PER $2.81-3.97$ at $5 \mathrm{~m}^{-3}$ density for 105 days culture period by applying floating feed supplemented with probiotics.

Water quality variables: Water quality variables were presented in Table 2.

Table 2. Water quality variables (mean \pm Sd) recorded from the cages under different treatments during the study period of July-November 2015

\begin{tabular}{lllll}
\hline \multirow{2}{*}{ Water variables } & \multicolumn{4}{c}{ Treatments } \\
\cline { 2 - 5 } & \multicolumn{1}{c}{$\mathrm{T}_{1}$} & \multicolumn{1}{c}{$\mathrm{T}_{2}$} & \multicolumn{1}{c}{$\mathrm{T}_{3}$} & \multicolumn{1}{c}{$\mathrm{T}_{4}$} \\
\hline Temperature $\left({ }^{\circ} \mathrm{C}\right)$ & $28.6 \pm 1.8$ & $28.7 \pm 1.9$ & $28.6 \pm 1.8$ & $28.7 \pm 1.9$ \\
Transparency $(\mathrm{cm})$ & $36.33 \pm 1.48$ & $35.62 \pm 1.25$ & $34.35 \pm 1.52$ & $35.28 \pm 1.31$ \\
Dissolved Oxygen (mg/l) & $4.92 \pm 0.81$ & $4.93 \pm 0.79$ & $4.91 \pm 0.80$ & $4.92 \pm 0.75$ \\
$\mathrm{pH}$ & $7.4(7.0-7.5)$ & $7.3(7.0-7.4)$ & $7.3(7.0-7.4)$ & $7.2(7.0-7.4)$ \\
Total alkalinity (mg/l) & $82.10 \pm 2.62$ & $83.11 \pm 2.70$ & $82.20 \pm 2.60$ & $82.15 \pm 2.58$ \\
$\mathrm{NO}_{3}-\mathrm{N}(\mathrm{mg} / \mathrm{l})$ & $0.11 \pm 0.03$ & $0.10 \pm 0.02$ & $0.12 \pm 0.03$ & $0.10 \pm 0.01$ \\
$\mathrm{NH}_{3}-\mathrm{N}(\mathrm{mg} / \mathrm{l})$ & $0.012 \pm 0.002$ & $0.012 \pm 0.001$ & $0.010 \pm 0.002$ & $0.013 \pm 0.003$ \\
\hline
\end{tabular}

Profit: Profit of tilapia farming as obtained in the present study was highest (TK. $401.00 \pm 83.35 \mathrm{~m}^{-3}$ ) in $\mathrm{T}_{3}$ followed by $\mathrm{T}_{2}$ (TK. $282.00 \pm 73.33 \mathrm{~m}^{-3}$ ) and $\mathrm{T}_{1}(\mathrm{TK}$. $212.00 \pm 70.3 \mathrm{~m}^{-3}$ ). The lowest profit (TK. $119.00 \pm 65.8 \mathrm{~m}^{-3}$ ) was found in controlled treatment (without probiotics, $\mathrm{T}_{4}$ ) (Fig. 2). Benefit cost ratio (BCR) was also highest in $\mathrm{T}_{3}$ (1.61) followed by $\mathrm{T}_{2}$ (1.43), $\mathrm{T}_{1}$ (1.32) and $\mathrm{T}_{4}$ (1.19) indicating that highest benefit was obtained from the treatment of zymetin probiotics $\left(\mathrm{T}_{3}\right)$ which may be due to the three beneficial bacteria and efficient utilization of the 
supplied feed. Production cost of zymetin probiotics treatment was more or less same as did the other treatments.

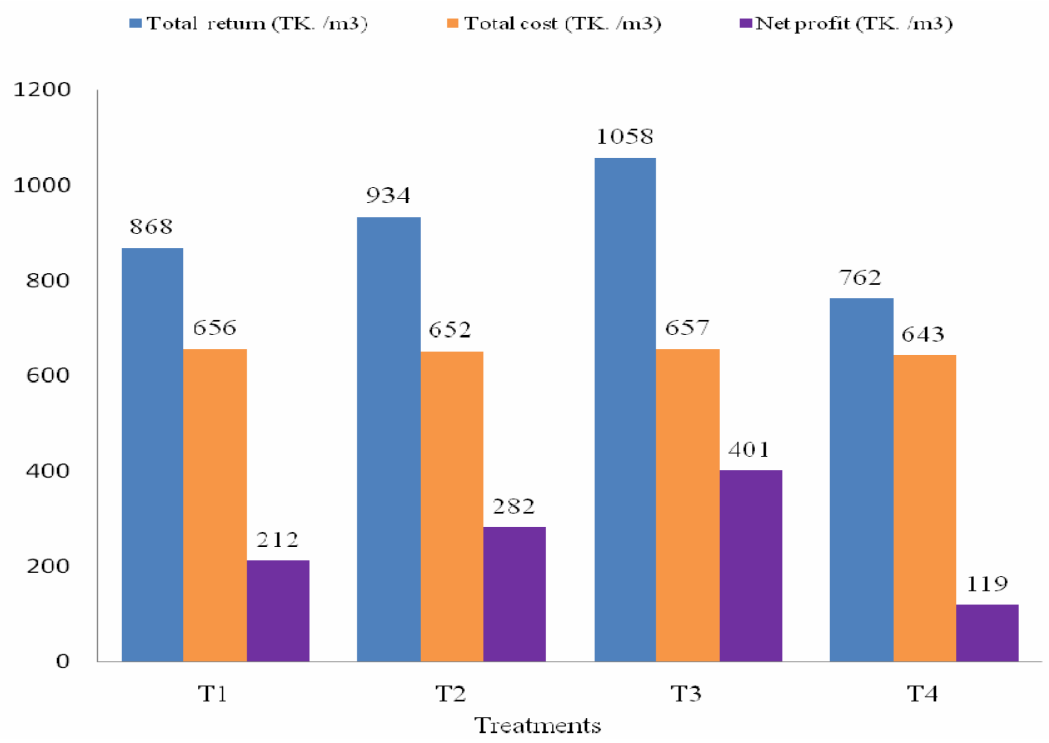

Fig. 2. Economic analysis of tilapia production in different treatments.

Results of the study demonstrated that zymetin probiotics treatment was better among the four in respect of survival rate, growth and fish yield. Therefore, it may be suggested to apply probiotics in tilapia cage culture system in the open/perennial waterbodies for increasing fish production with a satisfactory profit.

Acknowledgements: The authors are grateful to the authorities of Sylhet Agricultural University Research System (SAURES) for financial assistance. We are also deeply indebted to the reviewer for his untiring effort to improve the manuscript by necessary corrections, valuable advice and suggestions.

\section{LITERATURE CITED}

ABDEL HAMID, A. M., KHALIL, F. F. M. and El-Barbary, M. I. 2002. Feeding Nile tilapia Biogen to detoxify aflatoxin diets. In: Proceeding of the 1st Annual Scientific Conference of Animal and Fish production. Mansora University, Egypt 4938(5): 208-230.

AHMED, G. U., SUlTANA, N., SHAMSUDDIN, M. and HOSSAIN, M. B. 2013. Growth and production performance of monosex tilapia (Oreochromis niloticus) fed with homemade feed in earthen mini ponds. Pakistan J. Biol. Sci. 16(23): 1781.

AHMED, T., HASAN, S. J., HOSSAIN, M. R., A. HAIDAR, I., RUBEL, A. K. M. S. A. and PRAMANIK, M. H. 2014. Assessment on impact of dietary probiotic supplementation on growth indices of mono-sex tilapia (Oreochromis niloticus) cage culture at Dakatia river, Chandpur, Bangladesh. World Journal of Fish and Marine Sciences 6(5): 441-446. 
ALAM, M. B., ISLAM M. A., MARINE, S. S., RASHID, A., HOSSAIN, M. A. and RASHID, H. 2014. Growth performances of gift tilapia (Oreochromis niloticus) in cage culture at the old Brahmaputra river using different densities. J. Sylhet Agril. Univ. 1(2): 265-271.

AOAC (Association of Official Analytical Chemists). 2000. Official methods of analysis. 17th edition, Association of Official Analytical Chemists. Washington DC. 2200 p.

APHA (American Public Health Association). 2000. Standard methods for the examination of water and waste water. 18th ed., APHA, Washington, D. C.

BHUIYAN, B. R. 1970. Physico-chemical qualities of some ancient tanks of Sibsagar, Assam. Environmental Health 12: 129-134.

BOYD, C. E. 1982. Water quality management for pond fish culture. Elsevier Sci. Publ. Co., Amsterdam, The Netherlands $318 \mathrm{p}$.

BOYD, C. E. 1990. Water quality in ponds for aquaculture. Department of Fisheries and Allied Aquaculture. Auburn University, Alabama. 149 p.

CARNEVALI, C. and CRESCI, A. 2006. Growth improvement by probiotic European sea bass juveniles (Dicentrar chuslabrax L.), with particular attention to IGF-1, myostatin and cortisol gene expression. Aquaculture 258: 430-438.

DEWAN, S., WAHAB, M. A., BEVERIDGE, M. C. M., RAHMAN, M. H. and SARKAR, B. K. 1991. Food selection, selectivity and dietary over all among planktivorous Chinese and Indian major carp fry and fingerlings grown in extensively managed, rain fed ponds in Bangladesh. Journal of Aquaculture and Fisheries Management 22: 277-294.

DIANA, J. S., LIN, C. K. and YI Y. 1996. Timing of supplemental feeding for tilapia production. J. World Aquacult. Soc. 27: 410-419.

DOF (Department of Fisheries). 2016. National Fish Week Compendium (in Bengali). Department of Fisheries, Ministry of Fisheries and Livestock, Bangladesh. 126-131 pp.

ELLIS, M. M., WESTFALl, B. A. and ELLIS M. D. 1952. Determination of water quality. Fish and Wild Life Service, U.S. Dept. Interior, Res. Rept. 9: 122 p.

FAO (Food and Agriculture Organization). 2004. Fish stat Plus. Aquaculture Production 1950- 2002.

FITZSIMMONS, K. 2004. Development of new products and markets for the global tilapia trade. In: Proceeding of the 6th International Symposium on Tilpaia in Aquaculture, Manila, Philippines (ed. By R. Bolivar, G. Mair \& K Fitzsimmons), 624-633.

FULLER, R. 1992. History and development of probiotics. In: Fuller, R. (Ed.), the Scientific Basis, Champan \& Hall, London 232: 1-18.

GATESOUPE, F. J. 1999. The use of probiotics in aquaculture. Aquaculture 180: 147-165.

GEOVANNY, G. R., LUIS, B. J. and SHEN, M. 2007. Probiotics as control agents in Aquaculture. J. Ocean University of China (English Edition) 6(1): 76-79.

HUSSAIN, M. G. 2004. Farming of tilapia: Breeding plans, mass seed production and aquaculture techniques, $149 \mathrm{p}$.

ISLAM, M. L., PAL, H. K. and ALAM, M. J. 2008. Effectiveness of commercial probiotics as a biotechnological tool for shrimp (Penaeus monodon) health management. Project Completion Report 2006-08. Bangladesh Fisheries Research Institute, Brackishwater Station, Paikgacha, Khulna, Bangladesh. 15 p.

KUNDA, M., DEV, A. R. and ISLAM, M. J. 2015. Comparison of production performance and economics between mono-sex and mixed-sex tilapia (Oreochromis niloticus). SAU Res. Prog. Rep. No. 02, Sylhet Agricultural University, Sylhet, Bangladesh. 31-37 pp.

LIU, K. M. and CHANG, W. B. 1992. Biogenetic modeling of effect of fertilization, stocking density and spawning on growth of the Nile tilapia, Oreochromis niloticus (L.). Aquilt. Fish. Manag., 123: 271-280. 
MEADE, J. W. 1985. Allowable ammonia for fish culture. Prog. Fish cult. 47: 135-145.

MORIARTY, D. J. W. 1998. Control of luminous Vibrio species in penaeid aquaculture ponds. Aquaculture 164: 351-358.

MOYLE, J. B. 1946. Some indices at lake productivity. Trans. Amer. Fish. Soc. 26: 322 - 339.

PECHSIRI, J. and YAKUPITIYAGE, A. 2005. A comparative study of growth and feed utilization efficiency of sex-reversed diploid and triploid Nile tilapia, Oreochromis niloticus L. Aquaculture Research 36: 45-51.

ROY, H. C and WAHAB, M. A. 2014. Inclusion of prawn in polyculture: effects of stocking density of tilapia on environment and production. Advances in Fisheries Research in Bangladesh: Proc. of 6th Biennial Fisheries Conference \& Research Fair 2014. Bangladesh Agricultural Research Council and Bangladesh Fisheries Research Forum, Bangladesh. 246 p.

SAHA, S. B. and KHATUN, M. S., 2014. Production performance of monosex Nile tilapia, Oreochromis niloticus (Linnaeus, 1758) in brackishwater ponds. Bangladesh J. Zool. 42(2): 261-269.

SWINGLE, H. S. 1967. Standardization of chemical analysis for waters and pond mud. FAO Fisheries Report 4(2): 397-421.

(Manuscript received on 20 February, 2017; revised on 24 April, 2017) 